\title{
Virtual tour 3d penjara belanda Huis Van Behauring Bengkalis berbasis web
}

\author{
Devi Sukardi ${ }^{1}$, Rezki Kurniati, ${ }^{2}$ Kasmawi $^{3}$ \\ 1,2,3 Jurusan Teknik Informatika, Politeknik Negeri Bengkalis \\ Politeknik Negeri Bengkalis, JL. Bathin Alam, Sei Alam, Bengkalis \\ Email:1'devisukardi2107@gmail.com, ${ }^{2}$ Rezki@polbeng.ac.id ${ }^{3}{ }^{3}$ Kasmawi@polbeng.ac.id
}

\begin{abstract}
Abstrak
Bengkalis termasuk salah satu daerah yang memiliki peninggalan sejarah Belanda pada masa lampau, pentingnya usaha pelestarian dan pengenalan situs tersebut mendorong untuk membangun sebuah media informasi yang interaktif. Untuk mempromosikan informasi mengenai peninggalan sejarah tersebut dapat dilakukan dengan berbagai cara, salah satunya dengan dukungan visualisasi 3D yang menarik, sehingga membuat pengguna dapat mengetahui peninggalan sejarah yang terdapat di Bengkalis. Museum penjara Huis Van Behauring (bahasa Belanda) yang terletak di jalan Pahlawan Bengkalis akan dimuat ke dalam bentuk Virtual tour $3 D$ berbasis web. Virtual tour akan menampilkan animasi $3 D$ bangunan dan memberikan informasi mengenai sejarah bangunan tersebut melalui sebuah website, sehingga informasi dapat disampaikan secara umum. Objek Virtual tour 3D akan dibangun dengan menggunakan software Unity $3 D$ dan Blender agar menghasilkan Virtual tour museum penjara Huis Van Behauring (Jeil Dutch) peninggalan kota Bengkalis berbasis website yang interaktif.
\end{abstract}

Kata kunci: Blender, Huis Van Behauring, Virtual, Tour, Unity 3D

\begin{abstract}
Bengkalis is one of the areas that as several Dutch history heritage in the past, the importance of conservation efforts and the introduction of the site encourages to build an interacticve information media. To promote the information about historical heritage can be done in various ways, one of the way is with the support of interesting $3 D$ visualisation so that users can find out the historical relics found in Bengkalis. The Huis Van Behauring prison museum located on the Pahlawan Bengkalis street will be loaded into web-based. Virtual tour will display $3 D$ animation of the building of the provide information about the history of the building through a website, so that imformation can be submitted in general. 3D Virtual tour objects will be built using Unity $3 D$ and Blender software to produce a Virtual tour of the Huis Van Behauring (Jeil Dutch) prison museum of Bengkalis city-based interactive website.
\end{abstract}

Keywords: Blender, Huis Van Behauring, Virtual tour, Unity $3 D$

\section{Pendahuluan}

Bengkalis merupakan kabupaten dari Provinsi Riau, Indonesia. Wilayah kabupaten Bengkalis mencakup daratan bagian timur pulau Sumatera dengan luas mencapai 7.793,93 km². Suku Melayu merupakan mayoritas penduduk dari pulau Bengkalis Riau, sehingga memiliki peninggalan sejarah yang dikenal sangat kental budaya Melayunya.

Peninggalan sejarah yang terdapat dikota Bengkalis bukan hanya peninggalan bangunan Melayu saja, namun juga peninggalan sejarah bangunan penjara Belanda yang masih terawat oleh dinas Pariwisata dan Provinsi Riau, bahkan bangunan tersebut akan menjadi museum Provinsi Riau dan menjadi objek wisata Huis Van Behauring Bengkalis yang dapat dikunjungi oleh masyarakat umum. 
Penjara peninggalan Belanda Huis Van Behauring yang dibangun pada tahun 1880-an terletak di jalan Pahlawan kota Bengkalis yang merupakan bukti peninggalan zaman penjajahan Belanda. Pada awal tahun 2015 pihak dari dinas Pariwisata dan pihak dinas pendidikan dan kebudayaan (Disdikbud) Provinsi Riau banyak melakukan perbaikan atau pemugaran kembali di Huis Van Behauring mengingat banyaknya kunjungan wisatawan baik warga sekitar maupun wisatawan luar. Pemugaran yang dilakukan oleh Disdikbud dan Provinsi Riau merupakan proses untuk menjadikan Huis Van Behauring sebagai museum bersejarah tematik Provinsi Riau sesuai dengan undang-undang cagar budaya. Wawancara yang dilakukan oleh Bella Jeniska bersama Bapak Suhaimi, pada tanggal 13 Maret 2016 memperoleh informasi bahwa pada masa pemerintahan belanda yang dipimpin oleh E.H. Doorleben pada tahun 1883, seorang arsitek portugis mem asisten residen Belanda yang berada di Bengkalis membangun sebuah bangunan penjara yang hampir mirip dengan bangunan di Eropa, diketahui arsitek dari bangunan ini berasal dari Eropa namun tidak dikehahui nama dari arsitek tersebut [1].

Penjara Belanda Huis Van Behauring yang masih dalam masa pemugaran dari pihak Provinsi Riau belum dapat dikunjungi secara umum oleh masyarakat, sehingga masyarakat belum mengetahui bagaimana bentuk yang telah rehap oleh pihak Provinsi. Selain itu penyampaian informasi serta media promosi mengenai bangunan peninggalan Huis Van Behauring belum cukup menarik dan memadai. Hal ini dapat dilihat dari kurangnya informasi yang terkait dengan peninggalan sejarah tersebut baik informasi melalui website, media cetak, atau bidang promosi lainnya. Dari kondisi tersebut masyarakat tidak mengetahui seperti apa sejarah yang terdapat dibangunan Huis Van Behauring yang terletak di jalan Pahlawan, Bengkalis. Untuk memberikan informasi mengenai Huis Van Behauring dan menarik perhatian masyarakat umum terhadap peninggalan sejarah yang terdapat dikota Bengkalis maka informasi mengenai Huis Van Behauring akan dibuat dalam bentuk objek Virtual tour 3D yang mana pengguna dapat menjelajah langsung tanpa harus berkunjung ke lokasi.

Penelitian yang dilakukan oleh Dyah pada tahun 2015 yang berjudul media informasi sejarah Virtual tour 3 dimansi dari Candi Singosari di Kabupaten Malang menghasilkan sebuah aplikasi 3 dimensi Candi Singosari dimana pengguna aplikasi tersebut dapat mengelilingi situs sejarah Candi Singosari hanya dengan aplikasi[2].

Penelitian lainya pernah dilakukan oleh Fatchur 2014 yaitu visualisasi objek 3 dimensi menggunakan panorama 360 ${ }^{\circ}$ yang mempermudah menelusuri Museum Tugu Pahlawan di Surabaya dengan aplikasi[3]. Penelitian juga dilakukan oleh Mizaanatul 2013 dengan mengambil tema Mengenalkan Budaya Batik Jawa Tengah yang menghasikan prototype Virtual tour supermuseum batik Jawa Tengah [4].

Aplikasi Virtual Museum Sejarah Istana Siak berbasis desktop oleh supardi dkk 2017 juga menghasilkan lingkungan Istana Siak Sri Indra Pura secara virtual [5].Virtual tour 3D dapat diakses oleh masyarakat umum melalui website yang menggunakan bahasa pemograman HTML 5, html 5 merupakan versi terbaru dari HTML yang akan menjadi standar baru untuk XHTML dan DOM. [6]. Membangun sebuah objek 3D tidak hanya menggunakan aplikasi pendukung seperti Unity 3D dan Blender, namun untuk hasil lebih maksimal diperlukan Adobe Photoshop merupakan perangkat lunak yang digunakan untuk editing foto dan pembuatan efek. Pada objek 3 dimensi perangkat lunak ini digunakan untuk melakukan smooth pada setiap objek virtual tour yang akan digabungkan pada aplikasi unity 3D [7]. 


\section{Metode Penelitian}

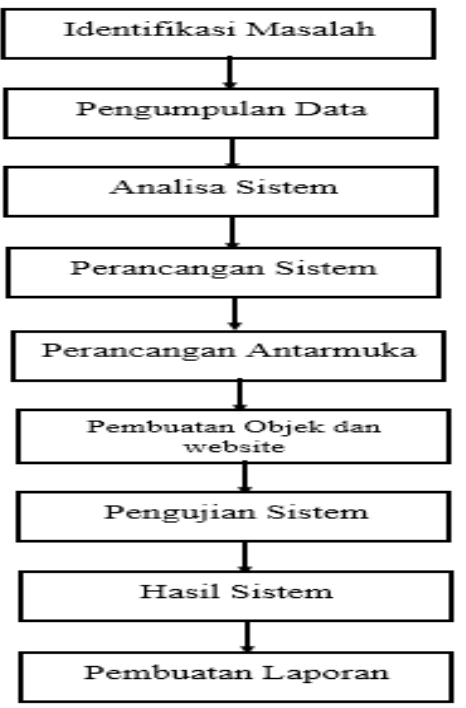

Gambar 1. Metode Penelitian

\section{a. Identifikasi Masalah}

Tahap awal melakukan penelitian ini dimulai dari mengidentifikasi masalah yang sedang terjadi dan masalah yang di identifikasi berdasarkan perumusan masalah. Memberikan jawaban sementara berdasarkan yang diketahui (hipotesa). Pada tahap ini juga menentukan objek dari bahan penelitian.

\section{b. Pengumpulan Data}

Metode pengumpulan data yang digunakan dalam penelitian ini adalah sebagai berikut :

1. Metode Wawancara

Penelitian yang dimaksud dengan metode wawancara adalah proses memperoleh keterangan mengenai suatu masalah dengan bertanya dan bertatap muka dengan seorang narasumber. Wawancara yang pernah dilakukan oleh Bella Jeniska pada tahun 2016 mengenai penjara belanda huis van behauring bersama Bapak Suhaimi, memperoleh sebuah informasi bahwa pada masa pemerintahan belanda E.H. Doorleben 1883, asisten residen bangunan sebuah penjara belanda yang mirip dengan bangunan di Eropa menggunakan jasa seorang arsitek yang berasal dari Portugis hal ini dapat dilihat dari bentuk bangunan bagian depan dari penjara.

2. Metode Studi Lapangan / Observasi

Penelitian yang menggunakan cara observasi yaitu sebuah penelitian yang dilakukan dengan mendatangi lokasi penjara belanda secara langsung serta mengamati segala perubahan yang terjadi seperti mengambil data dokumentasi dan ukuran penjara Huis Van Behauring.

3. Metode Studi Literatur

Dalam tahap pengumpulan data dengan metode ini yaitu mengumpulkan buku, jurnal, serta artikel terkait mengenai penelitian penjara Huis Van Behauring.

\section{c. Pembuatan Aplikasi dan Website}

Setelah melakukan pengumpulan data, tahap selanjutnya dalam penelitian ini adalah pembuatan objek Virtual tour 3D dan web, dalam tahap ini pembuatan aplikasi untuk objek menggunakan aplikasi Unity 3D [8], dan Blender (pemodelan object, pewarnaan)[9], website yang dibangun menggunakan bahasa pemrograman PHP serta menggunakan database MySQL sebagai tempat penyimpanan data. 


\section{d. Pengujian Aplikasi}

Tahap pengujian aplikasi untuk mengetahui sistem yang dibuat berjalan dengan baik. Pengujian dilakukan pada halaman website dan pengujian objek Virtual tour 3D yang telah di build ke WebGL.

\section{e. Hasil Sistem}

Hasil dari perancangan sistem ini berupa objek Virtual tour 3D Huis Van Behauring berbasis website yang dapat di akses oleh masyarakat umum guna mengetahui informasi yang terdapat dalam peninggalan sejarah Huis Van Behauring Bengkalis.

f. Pembuatan Laporan

Selanjutnya tahap pembuatan laporan dengan catatan jika semua tahap sudah dilakukan dan melaporkan dalam pembuatan sebuah sistem serta pengujiannya.

\subsection{Use Case Diagram}

Use Case Diagram merupakan gambaran umum tentang sistem [10] yang terdiri dari user dan admin. User bertindak sebagai pengguna dan admin bertindak sebagai pengelolaan sistem.

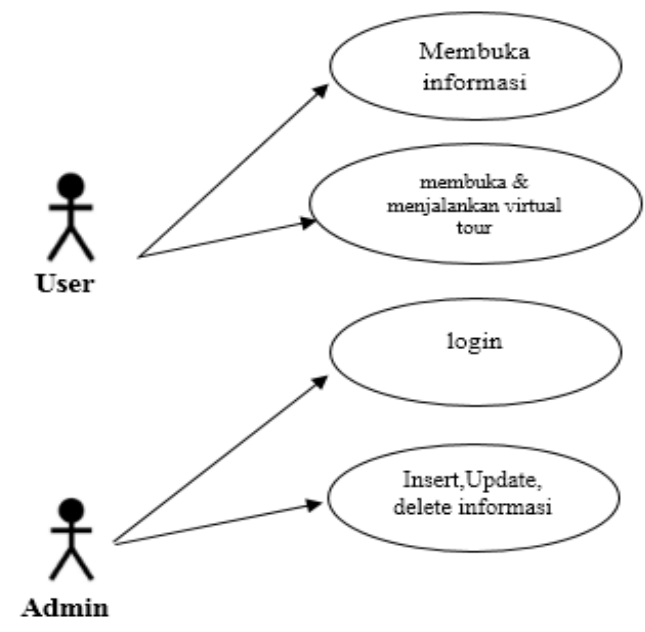

Gambar2. Use Case Diagram

\subsection{Perancangan Basis Data}

Perancangan basis data merupakan perancangan dari beberapa tabel dan field yang dibutuhkan. Beberapa tabel yang dibuat digunakan sebagai media untuk penyimpanan data yang akan diinputkan oleh pengguna sistem tersebut. Adapun perancangan basis data dari aplikasi Virtual tour 3D berbasis website yang akan dibangun adalah sebagai berikut:

a. Perancangan tabel Admin

$$
\begin{array}{ll}
\text { Nama Database } & \text { : app_virtual } \\
\text { Nama Tabel } & \text { :admin }
\end{array}
$$

Tabel 1. Perancangan Tabel admin

\begin{tabular}{|c|l|l|l|}
\hline No & \multicolumn{1}{|c|}{ Field } & \multicolumn{1}{c|}{ Tipe Data } & \multicolumn{1}{c|}{ Keterangan } \\
\hline 1. & id_admin & $\operatorname{int}(11)$ & Primary key \\
\hline 2. & Nama_admin & Text & Nama dari admin \\
\hline 3. & username & $\operatorname{Varchar}(30)$ & Username admin \\
\hline 4. & password & $\operatorname{Varchar}(30)$ & Digunakan untuk login \\
\hline
\end{tabular}


b. Perancangan tabel Informasi

Nama Database : app_virtual

Nama Tabel : tab_info

Tabel 2. Perancangan Tabel Informasi

\begin{tabular}{|c|l|l|l|}
\hline No & \multicolumn{1}{|c|}{ Field } & \multicolumn{1}{c|}{$\begin{array}{c}\text { Tipe } \\
\text { Data }\end{array}$} & \multicolumn{1}{c|}{ Keterangan } \\
\hline 1. & id_info & int(11) & Primary key \\
\hline 2. & judul_info & text & judul Informasi yang terkait \\
\hline 3. & isi_info & text & Isi dari infomasi terkait \\
\hline 4. & gambar & text & Gambar dari informasi \\
\hline 5. & waktu & timestamp & Waktu upload informasi \\
\hline
\end{tabular}

c. Perancangan tabel galeri

Nama Database : app_virtual

Nama Tabel : tab_galeri

Tabel 3. Perancangan Tabel galeri

\begin{tabular}{|c|l|l|l|}
\hline No & \multicolumn{1}{|c|}{ Field } & \multicolumn{1}{c|}{ Tipe Data } & \multicolumn{1}{c|}{ Keterangan } \\
\hline 1. & id_galeri & int(11) & Primary key \\
\hline 2. & judul_galeri & text & Judul Gambar yang di upload \\
\hline 3. & keterangan & date & Keterangan gambar yang di upload \\
\hline 4. & gambar & Varchar (5) & Bentuk gambar \\
\hline 5. & waktu & timestamp & Jam upload gambar \\
\hline
\end{tabular}

\section{Hasil dan Pembahasan}

Adapun hasil dari penelitian ini adalah sebuah aplikasi Virtual tour peninggalan sejarah Belanda yaitu Huis Van Behauring Bengkalis berbasis website, moddeling objek Virtual tour dibuat menggunakan aplikasi Blender sehingga menghasilkan animasi 3D, file objek 3D yang telah dibuat akan digabungkan menggunakan aplikasi Unity $3 D$ yang meliputi bagian penambahan Backsound, pengkodingan, pengaturan kamera, pencahayaan. Dan dalam website juga terdapat informasi sejarah mengenai Huis Van Behauring.

Pada aplikasi Virtual tour Huis Van Behauring berbasis website navigasi penggerak objek pengguna dapat melakukan tour dengan menggunakan keyboard top dan down untuk bergerak maju dan mundur, keyboard left, right untuk kekiri dan kekanan, kursor serta mouse dapat digunakan untuk berputar secara vertikal dan horizontal.

\subsection{Tampilan website}

Tampilan awal aplikasi Virtual tour 3D berbasis website ini dapat diakses pengguna secara umum, dimana halaman ini terdapat tiga pilihan menu yaitu menu informasi Virtual tour dan galeri. Button Go Virtual tour pada halaman awal, ketika di klik maka akan langsung menuju ke halaman Virtual tour penjara Huis Van Behauring.

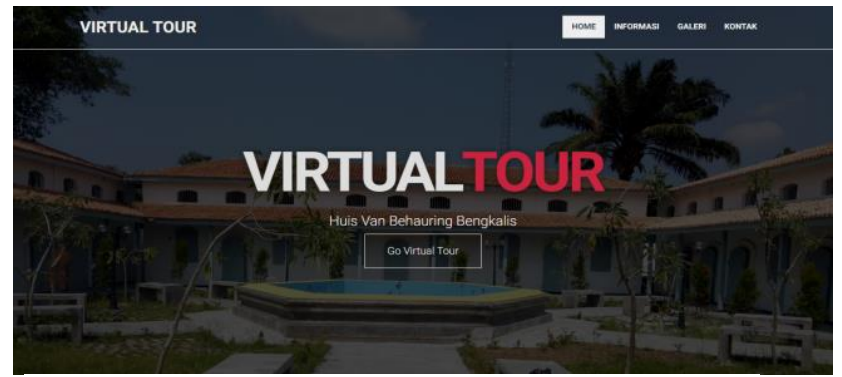

Gambar 3. Tampilan Halaman Awal Website 

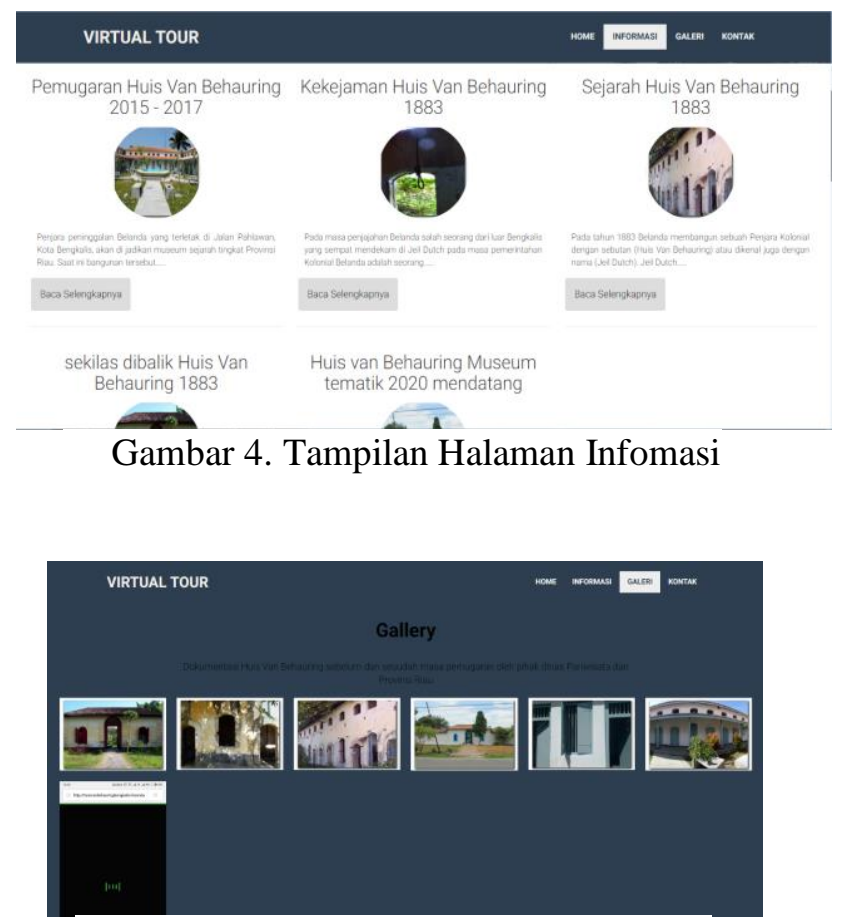

Gambar 5. Tampilan Halaman Galeri

\subsection{Virtual tour 3D}

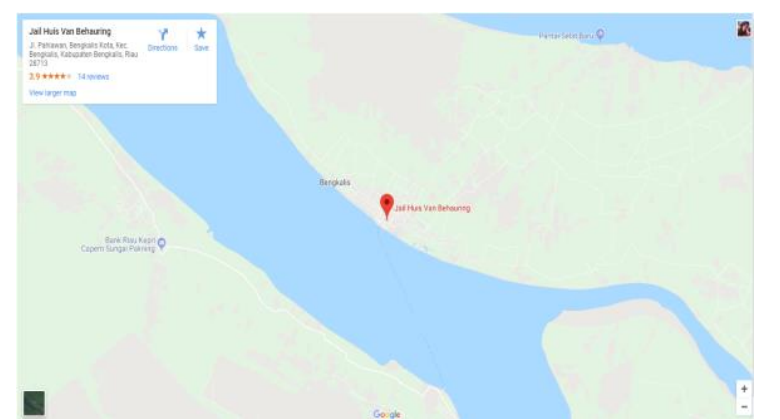

Gambar 6. Tampilan Halaman Lokasi pada Website

Output yang dihasilkan dari Virtual tour Pada tampilan ini merupakan sisi utama untuk memasuki bangunan Huis Van Behauring. Sisi utama pada halaman terdapat lorong yang mana bagian kiri dan kanan merupakan ruangan perkantoran yang digunakan untuk adminitrasi dan pelaporan. dapat dilihat pada gambar dibawah ini.

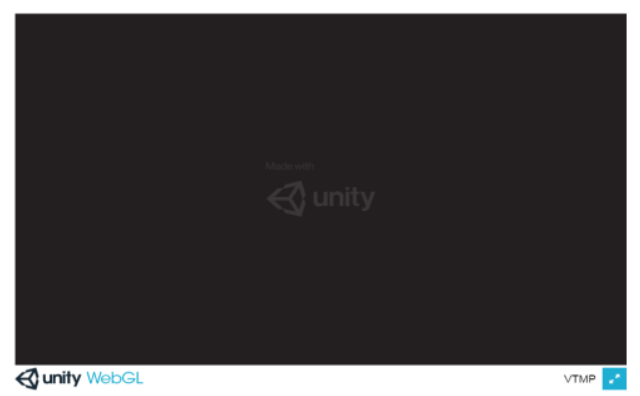

Gambar 7. Tampilan logo Unity 3D sebelum masuk ke Huis Van Behauring pada website 


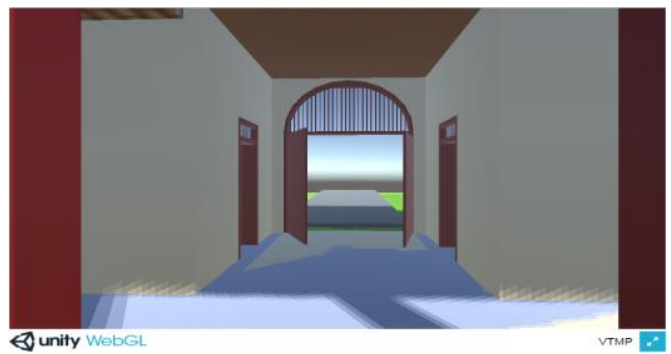

Gambar 8. Tampilan Virtual tour Huis Van Behauring pada website

Pintu utama digunakan sebagai salah satu sarana untuk memasuki area Huis Van Behauring. Pintu utama pada gedung utama terbuat dari kayu dengan bentuk setengah lingkaran diatasnya dan berukuran besar, setelah memasuki pintu utama dibagian depan sebelah kiri dan kanan bangunan terdapat kantor utama yang digunakan para sipir dan sekarang sudah direnovasi pada tahun 2016 seperti gambar di bawah ini.

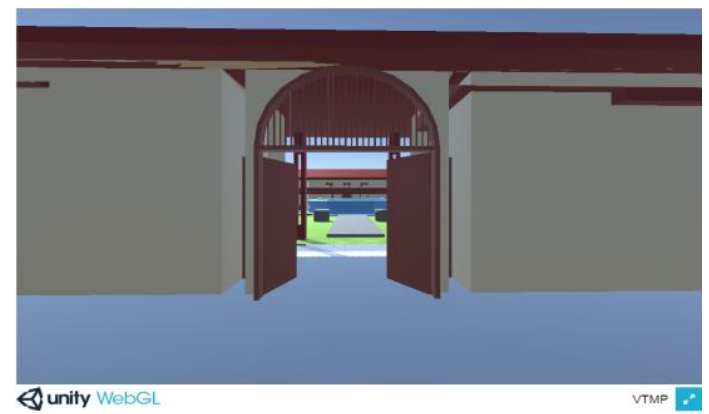

Gambar 9. Tampilan Pintu utama bagian luar penjara Huis Van Behauring

Penjara yang dibangun pada tahun 1883 oleh bangsa Belanda ini memakan waktu yang sangat lama, namun tidak di ketahui dengan pasti berapa lamanya pembangunan penjara itu sampai tiba masanya penjara itu di manfaatkan untuk tempat tahanan oleh pemerintah Belanda

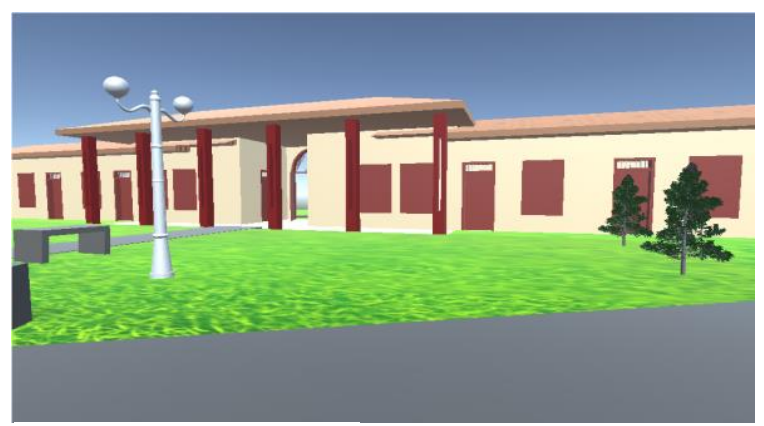

Gambar 10. Tampilan Ruangan utama 3D penjara

Huis Van Behaurin memiliki tembok utama atau tembok luar bangunan yang mempunyai bagian sisi yang sama yaitu dibangun dengan bentuk sebuah ruang segi empat dan digunakan untuk para pegawai penjara pada masa nya. Kantor utama pada gedung utama banyak digunakan oleh para sipir penjara untuk melakukan kegiatan seperti pelaporan kejahatan, pemberontakan dan seagainya. Kantor utama para sipir ini berada pada gedung utama didepan kanan dan kiri sebelum memasuki pintu utama. 


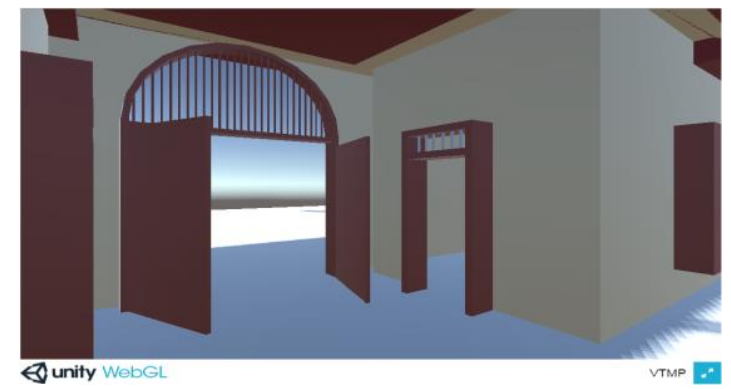

Gambar 11. Tampilan Kantor utama penjara Huis Van Behauring dari samping kanan

Pada bangunan Huis Van Behauring ini, mempunyai 23 sel yang dibangun serupa. Penjara untuk tahanan di bagian dalam terdiri dari bangunan bagian kanan ada 8 sel tahanan dengan ukuran sedang, sebelah kanan bagian depan terdapat 2 sel tahanan dengan ukuran kecil, bagian kiri ada 8 sel tahanan dengan ukuran sedang, sebelah kiri bagian depan terdapat 2 sel tahanan dengan ukuran kecil, dan pada bangunan belakang terdapat 3 sel berukuran besar.

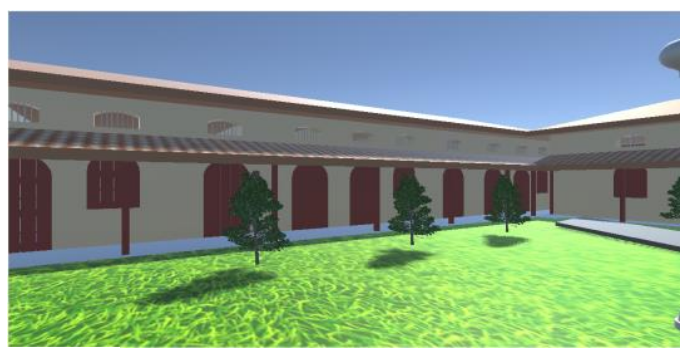

Gambar 12. Tampilan Sel tahanan 3D samping penjara Huis Van Behauring

Jeruji besi merupakan besi-besi yang dipasang disetiap jendela tahanan. Fungsi dari jeruji bei pada jendea yaitu agar tahanan tidak dapat melarikan diri. Jendela berjeruji besi tidak hanya terdapat pada sel tahanan namun juga terdapat di ruangan kantor pada gedung utama. Bedanya pada gedung utama jeruji untuk meghalangi jendela terbuat dari kayu.

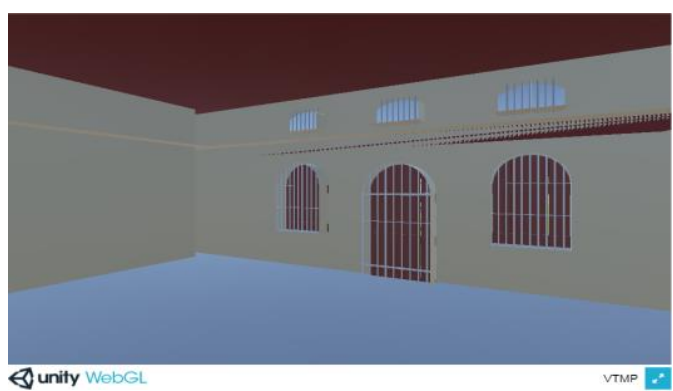

Gambar 13. Tampilan Sel tahanan dan penjara Huis Van Behauring

Huis Van Behauring yang dibangun oleh pemerintah Belanda, seharusnya pada tiap sisinya mempunyai sumur dan kamar mandi yang masih di renovasi oleh pihak provinsi.

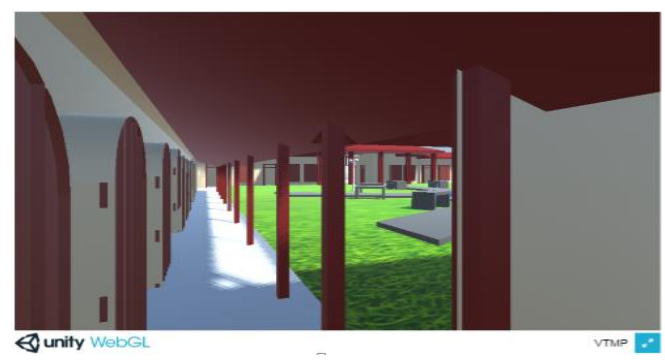

Gambar 14. Tampilan sudut sel tahanan 3D penjara Huis Van Behauring 


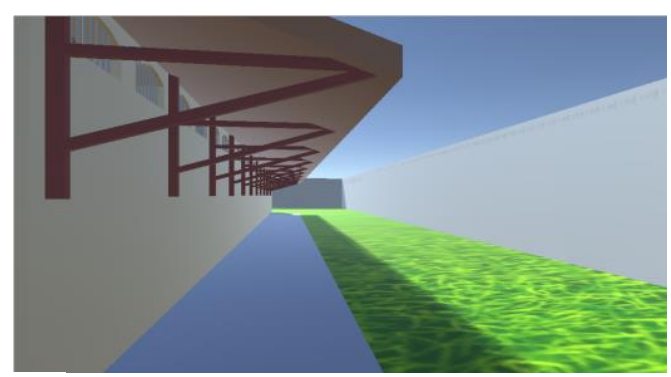

Gambar 15. Tampilan sudut belakang 3D tahanan penjara Huis Van Behauring

Pada awal tahun 2015 terdapat dua sel penjara yang terletak di tengah bangunan, dulunya sel tersebut merupakan tempat eksekusi para tahanan yang melanggar peraturan di Huis Van Behauring. Namun karena bangunan sel sudah sangat rusak dan ambruk maka pada awal tahun 2017 pihak dinas Pendidikan dan Kebudayaan Provinsi Riau membangun sebuah kolam air dan sarana tempat duduk bagi wisatawan yang berkunjung, namun kolam tersebut belum dapat difungsikan karena masih banyak pemugaran yang harus dilakukan.

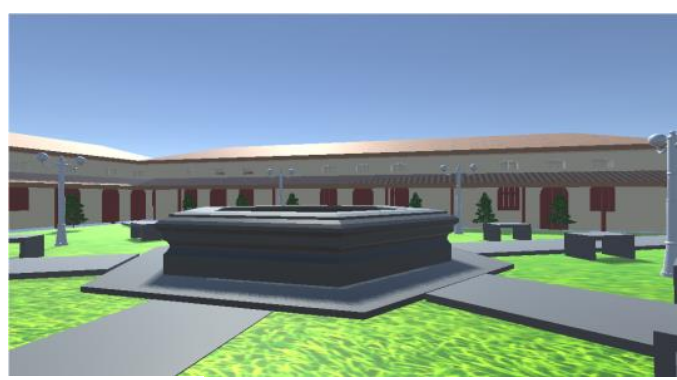

Gambar 16. Tampilan kolam air 3D penjara Huis Van Behauring

\subsection{Pengujian}

Tabel 4. Hasil Pengujian pada web browser

\begin{tabular}{|c|c|c|}
\hline No & Browser dan Aksi & Tampilan \\
\hline 1. & $\begin{array}{l}\text { Crome } \\
\text { WebGL telah diaktifkan pada } \\
\text { Google Chrome 13.0 dan versi } \\
\text { yang lebih baru menggunakan } \\
\text { Cross-asal untuk berbagi sumber } \\
\text { daya (CORS) dan untuk } \\
\text { mengontrol semua tekstur WebGL. }\end{array}$ & $\begin{array}{l}\text {-Tampilan website sesuai } \\
\text {-Button virtual pada keyboard PC dan } \\
\text { laptop berfungsi } \\
\text {-Bergerak kekiri dan kekanan } \\
\text { menggunakan kursor laptop dan mouse } \\
\text { berfungsi. }\end{array}$ \\
\hline 2. & $\begin{array}{l}\text { Monzilla Firefox } \\
\text { WebGL telah diaktifkan pada } \\
\text { Mozilla Firefox } 8.0 \text { dan versi yang } \\
\text { lebih baru untuk mengontrol } \\
\text { semua tekstur WebGL. }\end{array}$ & $\begin{array}{l}\text {-Tampilan website sesuai } \\
\text {-Button virtual pada keyboard PC dan } \\
\text { laptop berfungsi } \\
\text {-Bergerak kekiri dan kekanan } \\
\text { menggunakan kursor laptop dan mouse } \\
\text { berfungsi. }\end{array}$ \\
\hline 3. & $\begin{array}{l}\text { Opera Mini } \\
\text { WebGL telah diaktifkan pada } \\
\text { Opera 11, dan } 12 \text { keatas untuk } \\
\text { mengontrol semua tekstur WebGL. }\end{array}$ & $\begin{array}{l}\text {-Tampilan website sesuai } \\
\text {-Button virtual pada keyboard PC dan } \\
\text { laptop berfungsi } \\
\text {-Bergerak kekiri dan kekanan } \\
\text { menggunakan kursor laptop dan mouse } \\
\text { berfungsi. }\end{array}$ \\
\hline 5. & $\begin{array}{l}\text { Internet Explorer } \\
W e b G L \text { belum dapat diakses }\end{array}$ & Tidak sesuai dengan tampilan website \\
\hline
\end{tabular}




\begin{tabular}{|l|l|l|}
\hline melaui IE karena alasan & \\
keamanan, namun dukungan & \\
WebGL dapat secara manual & \\
ditambahkan ke IE menggunakan & \\
plugin pihak ketiga seperti & \\
Chrome Frame dan IEWebGL. & \\
\hline
\end{tabular}

\section{Kesimpulan}

Berdasarkan hasil pengujian aplikasi Virtual tour 3D Peninggalan Sejarah Bengkalis berbasis web, dapat ditarik kesimpulan bahwa Virtual tour penjara Huis Van Behauring ini belum dapat diakses oleh semua browser, hanya beberapa browser serta versi tertentu saja yaitu Google Chrome, Firefox dan Opera karena telah menggunakan teknologi WebGL, untuk browser Internet Explorer (IE) belum dapat mengakses WebGL, hal ini dikarenakan keamanan Internet Explorer (IE) masih kurang.

Keunggulan dari aplikasi Virtual tour 3D Huis Van Behauring berbasis web ini dapat membantu masyarakat umum dan wisatawan untuk lebih mengetahui informasi mengenai Huis Van Behauring melalui website. Selain itu pengguna aplikasi ini dapat menelusuri museum secara nyata dengan bantuan animasi 3D. Aplikasi ini dapat menjadi media promosi bagi Huis Van Behauring sebagai museum Tematik Provinsi Riau sehingga akan lebih mudah dan afektif.

\section{Daftar Pustaka}

[1] Bella. Development History Prisons (Jeil) Dutch Remainder at Regency Bengkalis. Pekanbaru, Program Studi Pendidikan Sejarah Jurusan Pendidikan Ilmu Pengetahuan Sosial Riau, Fakultas Keguruan Dan Ilmu Pendidikan Universitas Riau; 2014.

[2] Dyah. Media Informasi Sejarah Virtual Tour 3D Candi Singosari Kabupaten Malang. Malang, Jurusan Teknik Informatika, Politeknik Negeri Malang; 2015.

[3] Fatchur. Visualisasi Objek Dimensi Tiga pada Virtual Touring Panorama 360॰. Surabaya, Fakultas Teknologi Industri, Institut Sepuluh Nopember; 2014.

[4] Mizaanatul. Prototype Virtual Tour Museum pada E-Supermuseum untuk Mengenalkan Budaya Batik Jawa Tengah. Semarang, Fakultas Ilmu Komputer Universitas Dian Nuswantoro Semarang;2013

[5] Supardi, M, Danuri dan Prayitno, Aplikasi Virtual Museum Sejarah Istana Siak Sri Indra Pura Sebagai Media Promosi Dan Pelestarian Sejarah. Bengkalis, Jurusan Teknik Informatika, Politeknik Negeri Bengkalis; 2017.

[6] Edy. Pemrograman web berbasis HTML 5, PHP, \& JavaScript. Jakarta: PT Gramedia; 2014.

[7] Gregorius. Belajar Sendiri PHOTOSHOP CS5, Jakarta: Penerbit PT Elex Media Komputindo ;2010.

[8] Komputer, W. Mudah Membuat Game 3 Dimensi menggunakan Unity 3D : Penerbit Andi, 2014.

[9] Zaki, A., Winarto., dan Community. Animasi Karakter dengan Blender dan Unity, Jakarta: Penerbit PT Elex Media Komputindo ;2016

[10] Herlawati dan Widodo, Menggunakan UML : Informatika Bandung, 2011. 